\title{
RESEARCH PAPER \\ Non-technological innovations in Chilean agricultural firms: what motivates the decision to innovate and the propensity of innovation?
}

\author{
Rodrigo A. Fuentes, and Ariel R. Soto \\ Escuela de Administración y Negocios, Universidad de Concepción. Casilla 537, Chillán, Chile.
}

\begin{abstract}
R.A. Fuentes and A.R. Soto. 2015. Non-technological innovations in Chilean agricultural firms: what motivates the decision to innovate and the propensity of innovation? Cien. Inv. Agr. 42(2):171-179. Innovations are divided into four types: product, process, marketing and organizational (OECD, 2007). An extensive body of literature on the introduction of technological innovations in Chilean agricultural firms focuses on PP (product and process), but it is very limited with respect to groups of firms and non-technological innovations (MO, marketing and organization). The main objective of this article is to estimate the decision to innovate and the propensity to innovate in non-technological domains in Chilean agricultural firms. A zero-inflated count model is used to estimate, in a combined fashion, both innovation decisions and the propensity to innovate. Two versions of the Encuesta Nacional de Innovación (National Innovation Survey) were merged (2010 and 2012), and 403 agricultural firms were identified. Among the main results, the number of employees and the level of imports are found to positively impact the propensity to innovate in MO. Variables such as cooperation and networking with customers and suppliers are found to help push Chilean agricultural firms into innovative activity.
\end{abstract}

Key words: Agricultural firms, propensity to innovate, non-technological innovation, zero inflated count.

\section{Introduction}

Chile is one of the leading Latin-American agricultural markets and has an important position in the world's food market. It is one of the twenty most important producers of fruits and vegetables in the world (FAO, 2010). The same source indicates that Chile's main exports are fruit, wine, salmon and forest products. According to Chilean authorities, the country is viewed as a forestry and food power. All administrations

Received July 1, 2014. Accepted April 23, 2015. Corresponding author: arsoto@udec.cl over the last decade have had as one objective strengthening innovation as a national strategy. The results of the seventh National Innovation Survey (NIS) show that the agricultural industry has a low innovation rate $(13.6 \%)$ compared with electricity (40\%) and mining (35.7\%). The results of the eighth Survey are proportionately similar, with rates of 27.1, 49.6 and $45 \%$, respectively; this trend may be viewed as alarming or at least worthy of attention, considering the importance of agriculture in Chile. Between 2010 and 2012, $75.1 \%$ of all Chilean agricultural firms innovated in non-technological activities, such as marketing and organization (MO). The percentages were 
$25 \%$ and $58.3 \%$ for marketing and organization, respectively. One of the main questions about any innovation is whether it increases productivity significantly (Benavente, 2005). Moreover, according to the FAO, improving agricultural productivity offers three benefits: 1) economic growth and poverty reduction, 2) food safety, and 3) environmental sustainability.

There is an extensive body of literature on the adoption of technology by individual Chilean firms, in particular, on product and process innovation (PP). However, the literature on the agricultural sector in general and on the introduction of non-technological innovations (MO) in particular is limited. Regarding PP innovation, empirical studies in Chile show a positive correlation between such innovation and firm owners' education and age, their awareness of regulations, and the types of clients they serve (Nahuelhual et al., 2009). Vargas et al. (2002) studied organizational change in four Chilean agricultural firms and found that technological advances and the transformation of the labor market have led to changes in the management of human resources. Nevertheless, there is no evidence on the impact of innovation in Chile, especially non-technological innovation in the agricultural sector as a whole. In this article, we attempt to provide new insights on this topic.

Chile is the only country in South America that belongs to the Organization for Economic Cooperation and Development (OECD). However, as in every developing country, the agricultural sector is an important component of GDP. Additionally, traditional or technological innovations are deemed expensive; therefore, studying non-technological innovations in a relevant economic sector in a developing country may illustrate the importance of directing public resources to this type of innovation rather than merely to technological innovation. Some of the conclusions may be used in the implementation of public policies intended to improve agricultural production.
In research conducted in other countries, the factors considered in both types of innovation, $\mathrm{MO}$ and PP, are similar (Brown and Duguid, 1991; Kishore and McLean, 2002; Rammer et al., 2009; Yeh and Lung-Hung, 2007), although they may differ in their effects on decisions to innovate. The type of sector or industry to which they belong is also relevant (Schubert, 2010). Some of the most important factors that motivate innovation are personal features of firms' owners: age, education, and the type of administration they prefer (Stokes and James, 2005). Other authors have considered other factors, such as size, exports, indebtedness, age of the firm, legal status, and product diversification (Mel et al., 2009). Marsh (2004) establishes the most relevant variables in determining whether a firm has an innovative attitude: 1) stock of ideas, 2) demand for new products, 3) technological opportunities, 4) market structure, 5) characteristics of the firm, 6) appropriability of a new products or processes, and 7) interactions between institutions and institutional factors.

Finally, Armbuster et al. (2008) propose an organizational model of innovation that includes size of the firm, employees' qualifications, exports, product quality and an index of IT application as independent variables. We view this latest model as the providing the best fit with the NIS data, given the availability of variables. Moreover, networking with institutions is incorporated, as in Marsh.

The main objective of this article is to estimate the decision to innovate and the propensity to innovate in MO in Chilean agricultural firms. The propensity to innovate is a measure of innovative effort by the firm. For this purpose, we use a zeroinflated count model. The sample consists of 403 Chilean agricultural firms drawn from surveys from 2010 and 2012. The explanatory variables considered are four: i) human capital, ii) market (exports), iii) size (sales), and iv) networks. With respect to exports, the literature for Chile finds no clear causal effect of this variable on innova- 
tion (Bitran et al., 2014). However, our estimates show that for different specifications, exports are consistent in sign, magnitude and significance.

Data were retrieved from the seventh and eighth National Innovation Surveys, a comprehensive database that follows the standards of the OECD and the Community Innovation Survey (CIS) of Eurostat. These standards are the same as those described in the Oslo Manual, which is used to conduct surveys. There are two research questions: What factors motivate decisions to innovate in non-technological aspects of Chilean agricultural firms? And what variables determine the propensity to innovate?

\section{Materials and methods}

Eight explanatory variables are employed; four of these are continuous, and the remainder are binary. With regard to the former, the sales level represents the size of the firm $(S)$; the export level is a proxy for the firm's experience $(M)$ in the market (exports are also a measure of size, as they are measured in monetary units; note that exports and sales are non-collinear) (Majocchi et al., 2005); the number of employees and the proportion of qualified professionals in the firm are approximating measures of human capital $(H C)$. On the other hand, all categorical variables are linked to information sources with suppliers, customers and universities. Moreover, an additional variable indicates whether the firm engages in cooperative activities with other agents $(N)$. The values for the latter variables are based on firms' answers to the following questions: "Are suppliers a source of information for you?"; "Are clients a source of information for you?"; "Are universities a source of information for you?"; and "Do you engage in cooperative activities with other companies or institutions in any innovative activities?" Table 1 describes these variables.

Formally, the equation estimated for the supply of innovations is:
Innovation $_{i}=\beta_{0}+\beta_{1} S_{i}+\beta_{2} M_{i}+\beta_{3} H C_{i}+$ $\beta_{4} N_{i}+\gamma_{1} t+\gamma_{2}$ subsector $_{i}+\varepsilon$

where the dependent variable, a stock variable, represents a count of the innovative activities performed by each company $i$ :

$$
\text { Innovation }_{i}=j, \forall j=\overline{0,7} \in N
$$

The $\beta$ parameters are associated with the explanatory variables, and the $\gamma$ parameters are associated with control dummy variables such as $t$, which indicates the year to which an observation belongs ( $t=0$ for the 2011 survey, and $t=1$ for the 2013 survey), and the subsector variable, which indicates the agricultural subsidiary to which a company belongs (according to the code, ISIC Rev.3, the agricultural sector (sector A) is divided into two subsectors: 01 agriculture, livestock and game; and 02 forestry). Here, $\varepsilon$ represents errors of perception and optimization of the firm.

As is customary in models of innovation economics (Acs et al., 2002; Crepon et al., 1998; Crépon and Duguet, 1997), a count model has been adopted, following Gurmu and Trivedi (1996), who consider the quantity of innovative activities as the outcome variable. This is a two-step econometric process, as discussed in Labert (1992) and Greene (2008).

The count unit is commonly the quantity of patents requested (applied for); however, this is not a representative measure in the Chilean case, let alone for the agricultural sector in general because only $3.5 \%$ of agricultural firms possess an $\mathrm{I}+\mathrm{D}$ department (8 ${ }^{\text {th }}$ ENI report, 2013).

A zero-inflated count model is applied, as the vast majority of agricultural firms perform no innovative activities. A negative binomial distribution (ZINB) is applied, given the presence of significant overdispersion $-5 \%$, as determined by Vuong (1989) with a statistic of 4.58 ( $p$-value $=0.0000)$, see Figure 1. This is a modified version of a zero-inflated Poisson regression. The remarkable assumption of this model is that the expected value of the exponential error is 
Table 1. Descriptive variables.

\begin{tabular}{|c|c|c|c|c|c|c|}
\hline Dimension & Variable & Description & & $\begin{array}{l}\text { Innovative } \\
\text { Firms }\end{array}$ & $\begin{array}{l}\text { Non-Innovative } \\
\text { Firms }\end{array}$ & $\begin{array}{c}\text { Mean } \\
\text { comparison } \\
\text { Test }\end{array}$ \\
\hline \multirow{3}{*}{ Human capital } & \multirow{3}{*}{ Employees } & \multirow{3}{*}{ \# employees } & $\mathrm{N}$ & 78 & 325 & \\
\hline & & & Mean & 369 & 277 & \\
\hline & & & Std. Dev. & $1,969.21$ & $1,817.81$ & \\
\hline \multirow{4}{*}{ Market } & \multirow{2}{*}{$\begin{array}{l}\text { Technicians v/s } \\
\text { no-technicians }\end{array}$} & \multirow{2}{*}{$\begin{array}{l}\% \text { professionals } \\
\text { and technicians }\end{array}$} & Mean & $19.05 \%$ & $15.03 \%$ & \\
\hline & & & Std. Dev. & 20.77 & 20.28 & \\
\hline & Exports & US millions of & Mean & 4.38 & 1.37 & \\
\hline & & dollar & Std. Dev. & 0.74 & 7.32 & \\
\hline \multirow[t]{2}{*}{ Firm size } & \multirow[t]{2}{*}{ Sales } & \multirow{2}{*}{$\begin{array}{l}\text { US millions of } \\
\text { dollar }\end{array}$} & Mean & 8.60 & 7.03 & \\
\hline & & & Std. Dev. & 18.45 & 17.60 & \\
\hline \multirow[t]{4}{*}{ Networks } & Cooperation & $\begin{array}{c}\text { 1: realize } \\
0: \text { no realize }\end{array}$ & Mean & $30.77 \%$ & $3.38 \%$ & $* * *$ \\
\hline & $\begin{array}{l}\text { Network } \\
\text { customer }\end{array}$ & $\begin{array}{c}\text { 1: realize } \\
0: \text { no realize }\end{array}$ & Mean & $62.82 \%$ & $10.46 \%$ & $* * *$ \\
\hline & $\begin{array}{l}\text { Network } \\
\text { provider }\end{array}$ & $\begin{array}{c}\text { 1: realize } \\
0: \text { no realize }\end{array}$ & Mean & $66.67 \%$ & $11.08 \%$ & $* * *$ \\
\hline & $\begin{array}{l}\text { Network } \\
\text { university }\end{array}$ & $\begin{array}{c}\text { 1: realize } \\
0: \text { no realize }\end{array}$ & Mean & $67.95 \%$ & $11.69 \%$ & $* * *$ \\
\hline
\end{tabular}

Source: own calculations, based on the 7th and 8th National Innovation Survey.

$* * *$ and $* * *$ represent significance at 10,5 and $1 \%$ levels, respectively.

$1\left(e^{\varepsilon}=1\right)$, which is distributed according to Gamma. It is expected that these assumptions will allow for correct modeling of the overdispersion produced by the relative abundance of zeroes in the database. In this model, the parameters represent semi-elasticity. It is expected that the signs in the count model will be positive, implying positive effects of all variables on the quantity of innovative activities. As for the "inflated" part of the model, which is used to analyze the decision to innovate for the first time, it is expected that the signs of the parameters will be negative, thus implying that the probability of continuing without innovation decreases $\left(\right.$ Innovation $_{i}=0$ ).

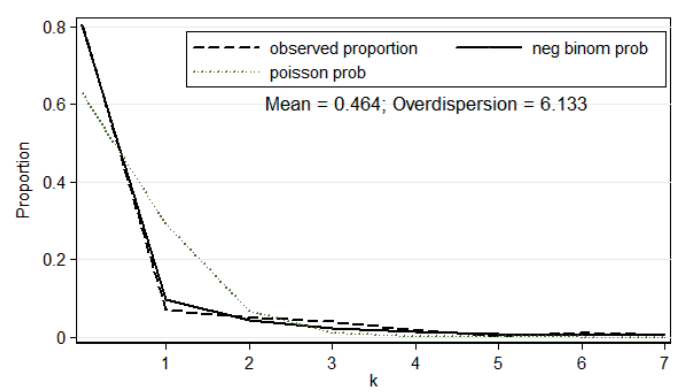

Figure 1. Adjustment capacity of count model with binomial negative distribution.
The ZINB model allows for the prediction, within the same estimation, of the parameters that influence the decision to innovate for the first time; that is, the amount of innovation goes from 0 to 1. This also applies to counts equal to or greater than 1 used to estimate other parameters. Following Winkelmann (2003), $c$ is defined as a binary variable that indicates whether a value is zero or non-zero. The variable defining innovative activities is $y_{j}$, which takes the following values:

$$
y=\left\{\begin{array}{lll}
0 & \text { if } & c=1 \\
y^{*} & \text { if } & c=0
\end{array}\right.
$$

The probability that $c=1$ is defined as $w$, and the probability of the function is:

$$
f(y)=w d+(1-w) g(y), \forall y=1, \ldots, 7
$$

where $d=\min \{y, 1\}$ y $g(y)$ is a negative binomial probability function. It is expected that, as the amounts of sales, exports, employees and qualified professionals increase, so will the probability of innovation and the volume of innovative activities. Additionally, if there are sources of 
information and cooperation, there should be a greater probability of innovation than if such networking did not exist. To test the stability of the model, two specifications are estimated for model (1). The first specification is used to estimate only the characteristics of the firms in the ZINB-count part, with all of the variables placed in the inflated part. In the second specification, all variables are estimated in the count part, and only the networking and cooperation variables are placed in the inflated part. The parameters in general are stable in terms of sign, significance and magnitude.

The advantage of the ZINB is that, in addition to simultaneously determining which factors lead to innovation for the first time and which factors increase the propensity to innovate, the dependent variable can be econometrically estimated as a discrete magnitude. The disadvantage lies in the fact that each innovative activity is built in an additive fashion, so it follows an order. That is, the model does not recognize the presence of activities with a higher relative weight in total innovation, but all contribute equally.

The predictive capacity of the count model shows a prediction error of $6.4 \%$, where Pearson's Goodness of Fit tests of $\chi^{2}$ indicate that the model is accurate, given the adjustment capacity between actual values and those predicted by the model (the null hypothesis is that the model can predict correctly, with 7-1 degrees of freedom) (Andrews, 1988a; Andrews, 1988b).

The database was constructed by merging the seventh (2009-2010) and eighth (2011-2012) National Innovation Surveys, designed by the Ministerio de Economía, Fomento y Turismo of Chile. The data gathering process was performed by the Instituto Nacional de Estadísticas (INE), Chile. The survey databases from 2009 and 2011 were populated with data from private firms owned by individuals or corporations that declared taxes in 2009 and 2011, respectively. The annual sales of these firms are over US\$100,000. The firms are studied using stratified sampling according to the classification of CIIU (Clasificación Internacional Industrial Uniforme; International Standard Industrial Classification, in English), Rev. 3, on a national scale. The sample frame was constructed from the databases of INE and the Servicio de Impuestos Internos (SII), Chile. Given the objectives of this research, the statistical validity of the estimated variables depends on internal representativeness in terms of activity, size and region.

Table 1 presents a description of the database. It is observed that agricultural firms that innovate in non-technological activities represent nearly $20 \%$ of the sample. The sample is characterized by national representativeness and by size. The average profile of a company that performs at least one innovative activity per year is as follows: it has 369 employees in total of which 19\% are qualified; it has annual exports of US\$4.38 million; and it has sales grossing US\$8.6 million. Among these firms, $30.77 \%$ performed at least one cooperative activity. Furthermore, $62.82 \%$ of these firms obtained information for their innovations through their relationships with customers, $66.67 \%$ through their relationships with suppliers and $67.95 \%$ through their relationships with universities. The data are highly variable, particularly the number of employees. Cooperative activities and networking with customers, suppliers and universities are variables that differ statistically in their mean values for innovative and non-innovative firms.

As a complement, Table 2 presents a test of mean differences, comparing innovative activities by sector. It may be observed that the agricultural sector differs from most of the sectors presented. This means that the propensity to innovate differs by sector; therefore, it is especially important to study the Chilean agricultural sector specifically. 
Table 2. Test of difference in mean values of the propensity to innovate by sector versus the agricultural sector.

\begin{tabular}{lc}
\hline Sectors & $\begin{array}{c}\text { Equality with Agricultural } \\
\text { sector }\end{array}$ \\
\hline Fishing & 0.2631 \\
Mining & 0.2507 \\
Manufacturing & $-1.9714^{*}$ \\
Energy & 0.0548 \\
Construction & -0.3712 \\
Retail & $-2.3415^{*}$ \\
Hotels & $-3.3361^{*}$ \\
Transport & $-2.0347^{*}$ \\
Financial intermediation & -0.5574 \\
Real estate activity & $-2.0321^{*}$ \\
Social services & $-2.3378^{*}$ \\
Other & $-3.3742^{*}$ \\
\hline indicates that the difference is significant at the 5\% level.
\end{tabular}

Table 3. Coefficient estimates for different specifications through ZINB.

\begin{tabular}{|c|c|c|c|c|c|c|}
\hline \multirow[b]{2}{*}{ Variable } & \multicolumn{2}{|c|}{ Model 1} & \multicolumn{2}{|c|}{ Model 2} & \multicolumn{2}{|c|}{ Final Model } \\
\hline & Count & Zero & Count & Zero & Count & Zero \\
\hline Employees & $\begin{array}{c}0.00018^{* *} \\
(7.9 \mathrm{e}(-5))\end{array}$ & $\begin{array}{c}0.0046 \\
(0.0049)\end{array}$ & $\begin{array}{c}0.00018^{*} \\
(8.2 \mathrm{E}(-5))\end{array}$ & & $\begin{array}{c}0.0002 * * \\
(9.37 \mathrm{E}(-4))\end{array}$ & $\begin{array}{c}0.0067 \\
(0.0093)\end{array}$ \\
\hline \%prof. \& tech. & $\begin{array}{c}0.0064 \\
(0.0047)\end{array}$ & $\begin{array}{l}-0.0054 \\
(0.0118)\end{array}$ & $\begin{array}{c}0.0072 \\
(0.0044)\end{array}$ & & $\begin{array}{c}0.0057 \\
(0.0045)\end{array}$ & $\begin{array}{c}-0.0016 \\
(0.01849)\end{array}$ \\
\hline Exports & $\begin{array}{c}0.0760^{* *} \\
(0.0312)\end{array}$ & $\begin{array}{l}0.08638 \\
(0.2651)\end{array}$ & $\begin{array}{l}0.05044^{*} \\
(0.0220)\end{array}$ & & $\begin{array}{c}0.0743^{* *} \\
(0.0299)\end{array}$ & $\begin{array}{c}0.1538 \\
(0.2566)\end{array}$ \\
\hline Sales & $\begin{array}{c}-0.0652 * * \\
(0.0274)\end{array}$ & $\begin{array}{l}-0.2973 \\
(0.3223)\end{array}$ & $\begin{array}{l}-0.0426^{*} \\
(0.0192)\end{array}$ & & $\begin{array}{c}-0.0676^{* *} \\
(0.0267)\end{array}$ & $\begin{array}{l}-0.4101 \\
(0.4065)\end{array}$ \\
\hline Cooperation & & $\begin{array}{c}-35.0097 * * * \\
(2.4799)\end{array}$ & $\begin{array}{c}0.1611 \\
(0.2242)\end{array}$ & $\begin{array}{c}-48.8815 * * * \\
(7.5692)\end{array}$ & $\begin{array}{c}0.2349 \\
(0.2231)\end{array}$ & $\begin{array}{c}-37.3570^{* * *} \\
(4.0156)\end{array}$ \\
\hline $\begin{array}{l}\text { Network } \\
\text { provider }\end{array}$ & & $\begin{array}{c}11.6162 * * * \\
(1.3527)\end{array}$ & $\begin{array}{c}0.3823 \\
(0.2742)\end{array}$ & $\begin{array}{c}11.42779^{*} \\
(7.3327)\end{array}$ & $\begin{array}{c}0.3786 \\
(0.2794)\end{array}$ & $\begin{array}{c}14.0117 * * * \\
(1.8954)\end{array}$ \\
\hline $\begin{array}{l}\text { Network } \\
\text { customer }\end{array}$ & & $\begin{array}{c}-32.4059^{* * *} * \\
(4.8507)\end{array}$ & $\begin{array}{l}-0.1948 \\
(0.2373)\end{array}$ & $\begin{array}{c}-28.1366^{* * *} \\
(10.3291)\end{array}$ & $\begin{array}{l}-0.1608 \\
(0.2394)\end{array}$ & $\begin{array}{c}-35.8855^{* * * *} \\
(9.538)\end{array}$ \\
\hline $\begin{array}{l}\text { Network } \\
\text { university }\end{array}$ & & $\begin{array}{c}-32.6587 * * * \\
(12.229)\end{array}$ & $\begin{array}{c}0.0599 \\
(0.3183)\end{array}$ & $\begin{array}{l}-17.6505^{*} \\
(10.7638)\end{array}$ & $\begin{array}{c}0.1244 \\
(0.3409)\end{array}$ & $\begin{array}{l}-34.9535 \\
(24.138)\end{array}$ \\
\hline DY & $\begin{array}{l}-0.4972 * \\
(0.3043)\end{array}$ & $\begin{array}{l}-75.8117 \\
(196.894)\end{array}$ & $\begin{array}{l}-0.4691 \\
(0.3039)\end{array}$ & $\begin{array}{l}-81.7965 \\
(169.627)\end{array}$ & $\begin{array}{l}-0.5092 \\
(0.3319)\end{array}$ & $\begin{array}{l}-1.1068 \\
(2.159)\end{array}$ \\
\hline DS & $\begin{array}{c}-48.3302^{*} \\
(29.724)\end{array}$ & $\begin{array}{l}-0.7941 \\
(2.0162)\end{array}$ & $\begin{array}{l}-45.6161 \\
(29.684)\end{array}$ & $\begin{array}{l}-0.9559 \\
(1.7388)\end{array}$ & $\begin{array}{l}-49.613 \\
(32.451)\end{array}$ & $\begin{array}{l}-106.431 \\
(210.807)\end{array}$ \\
\hline Constant & $\begin{array}{c}49.3415^{*} \\
(30.112)\end{array}$ & $\begin{array}{c}81.1440 \\
(199.708)\end{array}$ & $\begin{array}{l}46.3028 \\
(30.064)\end{array}$ & $\begin{array}{c}86.7636 \\
(172.161)\end{array}$ & $\begin{array}{c}50.231 \\
(32.779)\end{array}$ & $\begin{array}{c}111.929 \\
(213.663)\end{array}$ \\
\hline $\mathrm{N}$ & \multicolumn{2}{|c|}{403} & \multicolumn{2}{|c|}{403} & \multicolumn{2}{|c|}{403} \\
\hline Vuong & \multicolumn{2}{|c|}{7.32} & \multicolumn{2}{|c|}{3.90} & \multicolumn{2}{|c|}{4.58} \\
\hline Wald $\chi 2(10)$ & \multicolumn{2}{|c|}{19.21} & \multicolumn{2}{|c|}{29.26} & \multicolumn{2}{|c|}{28.42} \\
\hline
\end{tabular}




\section{Results and discussion}

Table 3 presents the estimates. The first part of the ZINB model shows the "count" (propensity), while the second part displays the "inflated" part (the decision to perform the first innovative activity). With regard to the first part, the number of employees and the level of exports positively affect the propensity to innovate in $\mathrm{MO}$; that is, both variables increase the number of innovative activities that the firm implements in non-technological domains. Armbrust et al. (2008) and Mel et al. (2009) also find a positive effect for the number of employees. De Mel et al. (2009) demonstrate that exports have a positive effect, although only on organizational innovations, not on marketing.

Sales takes a negative sign; that is, the propensity to innovate decreases with size. This sign is interpreted by observing that in the Chilean case, after agricultural firms reach a certain level of sales in the national market, given the scarcity of competition, their innovative activity decreases.

With regard to the second part, taking into account the negative signs of the parameters, networking with customers and suppliers push Chilean agricultural firms into innovative activity for the first time. Similarly, as explained by Nahuelhual et al. (2009), customers represent an important variable with regard to innovation or changing business practices. However, our results suggest that the influence of customers is meaningful for the initial decision to innovate but not for the propensity to engage in further innovation. With respect to networking and cooperation, our results support the evidence of Mash (2004). According to him, interactions with other institutions (cooperation and networking) determine the decision to innovate. In contrast to Armbrust et al. (2008) and Mel et al. (2009), employees and exports are not found to have meaningful effects.

It is noteworthy that the variables that motivate companies to innovate for the first time differ from those that motivate companies that already innovate to increase their innovative activities.

In Table 4, an incremental effect on the probability of innovating is observed for the variables associated with sources of information and cooperation. It can be inferred that as agricultural firms create networks with their suppliers, customers and universities - apart from agreeing to perform cooperative activities with other social/economic actors - the probability of performing at least one innovative activity increases considerably, from 1.68 to $73.61 \%$.

Cooperation by itself has a marginal effect, of $4.88 \%$, on innovative activity. Combinations of cooperative activity with both suppliers and customers have marginal effects on innovative activity -7.73 and $6.25 \%$, respectively. Nevertheless, the optimal combination for a company in this category is to establish cooperative activities and networking with universities, as such connections increase the probability of innovation by $61.56 \%$ above the probability of innovation by a firm with neither of these networks.

Table 4. Decision to innovate with different combinations.

\begin{tabular}{ccccc}
\hline Cooperation & Net Provider & Net Customer & Net University & $\begin{array}{c}\text { Probability to } \\
\text { innovate, \% }\end{array}$ \\
\hline No & No & No & No & 1.68 \\
Yes & Yes & Yes & Yes & 73.61 \\
Yes & No & No & No & 6.56 \\
Yes & Yes & No & No & 9.41 \\
Yes & No & Yes & No & 7.93 \\
Yes & No & No & Yes & 63.24 \\
\hline
\end{tabular}

Source: Prepared by the authors, based on estimates. 
This increment is striking mainly because in the final model, the parameter for University is not significant $(p-$ value $=0.110)$. However, the marginal effects are significant. Moreover, this parameter is significant in the three models that probe for stability (Table 3).

With regard to public policy recommendations, it is worth highlighting the importance of innovation in non-technological activities, as such innovation involves economic costs (time and money) that are lower than those associated with technological innovation, especially in the case of smaller-scale companies. The decision to innovate in MO for the first time by an agricultural firm differs from decisions to innovate a second time or multiple times. This is important with regard to designing policies that encourage innovative practices in agricultural firms, as it involves developing tools that will support the first innovation and different tools to help support subsequent innovations. According to our results, the number of employees, the level of exports and sales of an agricultural company are variables that influence the decision to innovate for the first time. Therefore, emphasizing these variables may enable better targeting of public resources when designing tools that will encourage companies to begin innovative activities in non-technological domains. A similar analysis can be performed for cooperation and networking with customers and suppliers, as these variables increase the propensity to engage in innovative activities. Therefore, it would make sense to design policy instruments that differentiate between companies that have never innovated from those that already do.

\title{
Resumen
}

\begin{abstract}
R.A. Fuentes y A.R. Soto. 2015. Innovaciones no tecnológicas en empresas agrícolas chilena: ¿qué motiva la decisión de innovar y su propensión? Cien. Inv. Agr. 42(2): 171-179. Hay cuatro tipos de innovaciones descritas: en producto, procesos, marketing y organización (OECD, 2007). Existe extensa literatura sobre la introducción de innovaciones tecnológicas en empresas agrícolas chilenas concentradas en PP (productos y procesos), pero es muy limitada en grupos de firmas y en innovaciones no tecnológicas, MO (marketing y organización). El objetivo principal de este trabajo es estimar la decisión y propensión de la actividad innovadora no-tecnológica en las empresas agrícolas chilenas. Se utiliza un modelo de Conteo Inflado con Ceros para estimar tanto la decisión como la propensión de innovar de manera combinada. Se fusionan dos versiones de la Encuesta Nacional de Innovación, 2010 y 2012, y se identifican 403 empresas agrícolas chilenas. De los principales resultados se destaca que la cantidad de empleados y el nivel de exportaciones afectan positivamente la propensión de la innovación en MO. La cooperación, las redes con clientes y proveedores son variables que empujan a las empresas agrícolas chilenas a una primera actividad innovadora.
\end{abstract}

Palabras clave: Conteo inflado con ceros, empresas agrícolas, innovación no tecnológica, propensión a innovar.

\section{References}

Acs, Z., L. Anselin, and A. Varga. 2002. Patents and innovation counts as measures of regional production of new knowledge. Research Policy 31: 1069-1085.
Andrews, D.W.K. 1988a. Chi-Square diagnostic tests for econometric models: Introduction and applications. Journal of Econometrics 37:135-156.

Andrews, D.W.K. 1988b. Chi-Square diagnostic tests for econometric models: Theory. Econometrica 56: 1419-1453. 
Armbruster, H., A. Bikfalvi, S. Kinkel, and G. Lay. 2008. Organizational innovation: the challenge of measuring non-technical innovation in largescale surveys. Technovation 28: 644-657.

Benavente, J.M. 2005. Innovación tecnológica en Chile: dónde estamos y qué se puede hacer. Economía Chilena 8: 53-77.

Bitran E., C. Gonzalez, F. Greve, and M. Villena. 2014. ¿Innovar para exportar o exportar para innovar? un análisis a nivel de firma de la industria manufacturera chilena, 1995-2010. Estudios Públicos 134: 109-130.

Brown, J.S., and P. Duguid. 1991. Organizational learning and communities-of-practice: toward a unified view of working, learning, and innovation. Organization Science 2: 40-57.

Crépon, B., and E. Duguet. 1997. Estimating the innovation function from patent numbers: GMM on count panel data. Journal of Applied Econometrics 12: 243-263.

Crepon, B., E. Duguet, and J. Mairessec. 1998. Research, innovation and productivity: an econometric analysis at the firm level. Economics of Innovation and New Technology 7: 115-158.

FAO and OCDE. 2010. OECD-FAO Agricultural Outlook 2010. OECD Publishing.

Greene, W. 2008. Functional forms for the negative binomial model for count data. Economics Letters 99: 585-590.

Gurmu, S., and P.K. Trivedi. 1996. Excess zeros in count models for recreational trips. Journal of Business \& Economic Statistics 14: 469-477.

Kishore, R., and E.R. McLean. 2002. The next generation enterprise: a CIO perspective on the vision, its impacts, and implementation challenges. Information Systems Frontiers 4: 121-138.

Lambert, D. 1992. Zero-inflated Poisson regression, with an application to defects in manufacturing. Technometrics 34: 1-14.

Majocchi, A, E. Bacchiocchi, and U. Mayrhofer. 2005. Firm size, business experience and export intensity in SMEs: A longitudinal approach to complex relationships. International Business Review 14: 719-738.

Marsh, D. 2004. An Investigation into the Determinants of Innovation in the New Zealand Bio- technology Sector. Thesis. The University of Waikato. Waikato, New Zealand. 303 pp. Available online at: http://researchcommons.waikato. ac.nz/handle/10289/2549 (Website accessed: March 2, 2014).

Mel, S., D. McKenzie, and C.M. Woodruff. 2009. Innovative Firms or Innovative Owners? Determinants of Innovation in Micro, Small, and Medium Enterprises. SSRN Scholarly Paper ID 1336059. Rochester, NY: Social Science Research Network.

Nahuelhual, L., M.A. Engler, B. Carrillo, V. Moreira, and I. Castro. 2009. Adoption of cleaner production practices by dairy farmers in southern Chile. Ciencia e Investigación Agraria 36: 97-106.

Rammer, C., D. Czarnitzki, and A. Spielkamp. 2009. Innovation success of non-R\&D-performers: substituting technology by management in SMEs. Small Business Economics 33: 35-58.

Schubert, T. 2010. Marketing and organizational innovations in entrepreneurial innovation processes and their relation to market structure and firm characteristics. Review of Industrial Organization 36: 189-212.

Stokes, D., and M. James. 2005. Changing the capital: innovation in London's small firms. Journal of Research in Marketing and Entrepreneurship 7/8: 95-106.

Vargas, G., R. Paillacar, and W. Foster. 2002. Efecto de las características de la empresa en la administración de recursos humanos: cuatro estudios de casos de empresas agrícolas grandes chilenas. Ciencia e Investigación Agraria: Revista Latinoamericana de Ciencias de la Agricultura 29: $13-28$

Vuong, Q.H. 1989. Likelihood ratio tests for model selection and non-nested hypotheses. Econometrica 57: 307-33.

Winkelmann, R. 2003. Econometric Analysis of Count Data. Springer. New York, USA. 302 pp.

Yeh, Y.J.Y, and L.H Chou. 2007. Transforming a semiconductor company into a learning organisation: a bottom-up approach of knowledge management implementation. International Journal of Technology Management 39: 219 234. 
